\title{
A FAVOR DE LAS RANAS Y DE SU CONDICION PERDIDA
}

Antonto SANCHEZ

Prof. del I.B. de Cuellar

Que no

se vea en este escrito una apologia de los principados, sino un alegato a favor de que las ranas recuperen su perdida condjeión

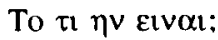

El tema de la metáfora ocupaba tradiclonalmente a los lingüistas y se situaba en el marco de la Estilistica: sin embargo, el discurso fllosóflco ha ido paulatınamente tomando contacto con él y descubriendo su importancla en el proceso de recreación del lenguaje. De tal manera que ahora podemos encontrar una abundante blbliografia que aborda el problema de la metáfora desde las más diversas perspectivas. Este articulo se suma a ellas, pues tiene como objeto de estudio la definición de "metáfora", y atiende, además, a las implicaciones ontológı́cas que conlleva tal Interés. Es preciso señalar que, para llevar a cabo esta reflexión, nos hemos visto obligados a seleccionar entre los numerosos ensayos fllosóficos sobre el tema que nos ocupa, aquellos desde los que pudiera plantearse no sólo el problema de la definición de "metáfora", sino también dos cuestiones primordiales: la razón de la existencla de la metáfora (su necesidad en el dominio lingüistico) y su modo de operación (la forma en la que se desarrolla el "acto metafórico"). Asi pues, los escritos seleccionados como bases de esta investigación son los siguientes:

-Metáfora y realidad, de Philip Wheelwright, especialmente los capitulos que tratan de las relactones entre la metáfora, el simbolo arquetipico y el mito.

- El mito de la metáfora, libro en el que el profesor Colin Murray Turbayne estudia la incidencla de las construcciones metafóricas en la creaclón de modelos de conceptualización (sobre todo el carteslano mundo de la "gran maquina" ). 
- La deshumanizactón del arte y otros ensayos de Estèttca, colección de ensayos de Ortega. Dos tratan en especlal de la metáfora: "El tabú y la metáfora" y "Ensayo de Estética a manera de Prólogo".

También deben ser reseñados dos breves comentarios que ofrecen sugerentes perspectivas:

-"La metáfora", unas líneas en la Historia de la eternidad de Jorge Luls Borges y

-"Encogimiento de hombros", fragmento 36 del Libro del desasosiego de Fernando Pessoa.

Como este articulo pretende entrar en discusión con las teorias que se presentan en las obras mencionadas, antes de pasar a exponer las apreciaciones que constituirán la base critica, resumiremos las líneas generales de los estudios ya indicados, comenzando con la definición de metáfora de Phllip Wheelwright.

La definiclón de metáfora de Phllip Wheelwright

Phillp Wheelwright dedica gran parte de su obra mencionada a perflar una definición de "metáfora" tomando como punto de partida la definición que ya propusiera Arıstóteles en su Pótica. La metáfora es la transferencia de un nombre a un objeto que habitualmente no lo posee. Según Wheelwright, la fuerza de una metáfora esenclal no reside en ninguna regla gramatical, sino en las posibilidades de transformación semántica que comporta. Podríamos aflrmar pues, utllizando un término más adecuado, que la metáfora consiste en "metamorfosis", y que la poesia, el máximo esfuerzo del arte y del declr metafórico, no es sino el lenguaje simbólico de la metamorfosis. Metamorfosis cuyo propósito es intensificar nuestro sentido de la realidad. De tal manera que la poesia no es sino el resultado de la acción de una imaginación sobre otra, mediante el instrumento de la metáfora.

Wheelwright nos propone pues la comprensión del fenómeno metafórico como fenómeno metamórfico. lo cual supone ya un acercamlento al concepto de ser que soporta la metáfora: la realidad apresada en el nombre es "transformada" por la imaginación en el acto metafórico.

Lo que realmente importa en una metáfora -prosigue Wheelwright-es la profundidad psíquica a la que las cosas del mundo, reales o fantásticas, son transportadas por la serena vehemencla de la Imagı́nación. El proceso de transmutación que ello implica puede ser descrito como un moutmiento semántico en el cual cabe distinguir dos momentos: 
a) epifora, superación y extensión del significado mediante la comparaclón:

b) diáfora, creación de nuevos sentidos mediante la yuxtaposición y la sintesis.

En primer lugar, el movimiento de la epifora se caracteriza por pasar de una imagen más concreta y más fácilmente aprehensılble a o sobre (epl) otra más vaga, más problemática y extraña. Una epífora, por tanto, presupone una Imagen o noclón vehicular fácil de comprender; esto es, una palabra del léxico habitual, un concepto cotidlano.

De ello no se sigue que la semejanza entre vehiculo y tenor (entre nombre y transmutación metafórica) haya de ser obvla -destaca Wheelwright- nl la comparación explicita: una semejanza ya obvia no proporclonaría ningún tipo de tensión. Las mejores epiforas se distinguen por su novedad, pues éstas llaman la atención hacia semejanzas no advertibles a primera vista e Implican una percepción intuitiva de la desemejanza de lo desemejante. Por consiguiente, el secreto de la epifora, su sortilegio, radica en la consecución de un adecuado equllibrio entre la tensión que produce el encuentro de las dos imágenes y la comprensión que se pretende al enfrentarlas.

En segundo lugar, Wheelwright habla de diafora, de "movimiento diafórico", un movimiento que se produce al reunir ciertos aspectos de la expertencla (real o imaginada) de un modo nuevo que suscita un nuevo significado por simple yuxtaposiclón. La diáfora sería en poesía la pura presentación de diversas particularidades en una disposición nueva.

Desde esta perspectiva Wheelwright recoge definiciones clásicas de metáfora que Inciden en este aspecto diafórtco. Asi, Coleridge habla del carácter "esemplástico" de la metáfora, carácter que consiste en difundir un tono y espiritu de unidad que mezcla y funde cada cosa con las demás: Shelley destaca en el lenguaje metafórico su capacidad para descubrir las antes inadvertidas relaciones entre las cosas, y, por ültimo, tamblén el autor reflere la opinłón de E. Jordan, para el cual la metáfora es la afirmación de una individualidad, la afirmación mediante la cual un complejo de cualidades reales deviene un individuo, se affrma como real.

Como hemos podido apreciar, la opinión de Wheelwright no se aparta en lo esencial de los criterios clásicos; la metáfora es transposición. transmutación del nombre de una cosa por el nombre de otra, $y$, por consigulente, de una cosa por otra. El acto poético, dominio proplo de la metáfora, se vislumbra según esta versıón como un proceso metamórfico, un acto en el que las caras de las cosas se concretan mediante las caras de otras cosas que mantienen con aquellas "simpatias ocultas". Y esto sí que es interesante: los nombres pasan en el acto metafórico a un estado de 
fustón del cual salen renovados, rehechos, con los nuevos perflles que se han dado unos a los otros.

En estas lineas Wheelwright no ha extendido explicitamente el poder metafórico al habla cotidiana, y lo ha clrcunscrito únicamente al hacer poético. Sin embargo, como veremos más adelante, aceptará esta extensión cuando trate las consecuenclas de su discurso.

La definicion de metafora de C.M. Turbayne

Turbayne enmarca el problema en un ámbito que ya desde un comienzo desborda los estudios de Estilistica. Decir que la metáfora es la técnica de la poesia -asegura Turbayne- es una noclón común entre lingülstas. Sin embargo, él está convencido de que la metáfora no es sólo un modo semántıco normal, sino tamblén un modo esencial a la existencla $\mathrm{y}$, sobre todo, a la expansión de las funciones semánticas del lenguaje. Es la única manera con que contamos para decir algo nuevo.

El punto de partida sitúa el problema de la metáfora en los limites que nos interesan. Si la metáfora únicamente fuera un recurso de "estllo", su dominlo atañeria con propledad al poeta, y su clariflcación al critıco de arte. Tal vez podriamos Inmisculmos en las pretensiones de estos "profesionales" postulando la radicalidad poética de todo acto de lenguaje humano, pretenstón que sin duda con blzarria nos sería posible sostener. Empero, Turbayne evita discusiones colảndose por la puerta de atrás. El acto metafórlco no es propiedad del poeta: es, en mayor medida, un modo esencial a la existencla $y$, por supuesto, a la existencla humana que es Irrevocablemente lingüistica. De tal modo que, si la metáfora es el fundamento de todo acto poético, entonces el lenguaje humano en sus momentos decisivos -aquéllos en los que se trata de decir algo nuevo, el decir "radical"- es tamblén poesia. O perfllando aún más: la poesia no es más que una concentración, un exceso del acto lingüistico genético. Desentrañando el hilo de la metáfora descubriremos, pues, el proceso de creación de la palabra y, además, tamblén vislumbraremos uno de los modos esenclales de la existencia. El estudio de la metáfora nos ofrece. pues, compensaciones existenciales. Sigamos la indagación de Turbayne.

Como Wheelwright, parte Turbayne de la definlción de Arlstóteles, y extrae las sigulentes consecuencias: el uso de la metáfora implica la suposiclón de que algo es cuando no lo es; sólo a veces el autor revela que dicha suposición está implicita. Este empleo conlleva pues, tanto la conciencla de la dualidad de sentido, cuanto la simulación de que los dos sentidos diferentes son uno solo. La metáfora nos da dos ideas como st fueran una. Por tanto la metáfora -de acuerdo con Gllbert Ryle- "expone los 
hechos... como si pertenecieran a un tupo o categoria lógica, cuando en realidad pertenecen a otra". Los efectos de tal "confusión y uniflcación de sentido" no son justamente la ocultaclón, sino tolo lo contrarlo. Citando a Black. Turbayne señala que "una metáfora eficaz actúa como una pantalla a través de la cual contemplamos el mundo; o blen filtra los hechos, suponlendo algunos y ponlendo en relieve otros".

La consecuencia ontológı́ca de semejante instrumento de enfoque pone en evidencla el poder "desvelador" de la metáfora: un camblo de acttud (un camblo de perspectiva) hacia los hechos puede incluso provocar un camblo efectivo. Aflrmación mediante la cual Turbayne sostlene que el camblo metafórico no sólo afecta a las palabras, sino tamblén a las cosas nombradas.

Una vez que ha planteado estos fundamentos de reflexión, el autor Indaga en la vida de las metáforas. Este capitulo es especialmente importante en su estudio, pues busca Turbayne sobre todo la génesis de las metáforas que han dirigıdo la construcción del lenguaje cientifico moderno (en Descartes, Hume, Newton), y, por consiguiente, su concepción del mundo.

En su opinión, podemos distinguir tres etapas principales en la vida de una metáfora:

a) comienzo fortuito: empleo inadecuado de una palabra: se le asigna a una cosa un nombre que pertenece a otra.

b) éxito: si dicho empleo es eflcaz, rápidamente entra en la segunda parte de su vida; el que una vez fuera nombre inaproplado se convierte en metáfora. Aceptamos la metáfora consintiendo en el artiflcio. Turbayne no señala en que estriba el éxito de una metáfora, problema éste que, indudablemente, no podemos soslayar.

c) muerte de la metáfora: la metáfora se oculta: el sentudo orlginal se ha perdido para la mayoria de nosotros y el sentido metafórico se interpreta como sentido literal. Del suponer o fingir se ha pasado al creer. Ayudan a que se produzca tal confusión los siguientes factores:

- las dos Ideas ya comparten el mismo nombre:

- no sleinpre se nos advierte que las dos ideas son en realidad diferentes:

- Incluso aunque se nos haga la salvedad correspondiente, traspasamos propledades de una idea a otra.

Desarrollo de la metáfora segün Wheelwright 
Para ahondar un poco más en el proceso de génesis y muerte de la metáfora, antes de pasar a la valoración de lo anteriormente expuesto. quizás sería conveniente contar con otra perspectiva y retomar las páginas de Wheelwright.

Aflrma éste que la metáfora puede hacerse estable y permanente y convertirse en simbolo tensivo. El simbolo tensivo tiene dos caracteristicas que lo diferenclan de los estenosímbolos (los simbolos convencionales de las ciencias o de los lenguajes artificiales). Por una parte, el símbolo tensivo no puede ser totalmente estipulativo: toma vida de una multitud de asociaciones inconsclentes que el simbolo innova o reactualiza. En segundo lugar, el simbolo tensivo no pretende la exactitud: oculta para desvelar.

Socialmente, el espectro de utllización de los símbolos es muy amplio, de tal forma que puede varlar desde el empleo más privado hasta la signiflcación arquetipica. Wheelwright ofrece una lista de cinco ocurrencias tipicas:

1) El simbolo es la imagen que preside un determinado poema;

2) es repetido y desarrollado por un poeta como dotado de especial importancia y sıgniflcactón para él;

3) puede ser, en mayor medida, el elemento común de toda una tradición literaria;

4) o signiflcativo para todo un grupo cultural o una confesión religiosa:

5) y en último lugar, incluso arquetipico, dotado de una signiflcación semejante para todos los humanos.

Wheelwright presta especial atención a estos últimos, a los símbolos tensivos arquetipicos. Su repetición en culturas remotas sin contactos culturales le parece posible desde el momento en que tales simbolos están basados en semejanzas naturales de las dimensiones fisica y psiquica del hombre. Tales semejanzas coinciden en gran manera con las disposiciones corporales que Lakoff \& Johnson citan en su obra Metáforas de la vida cotidiana. Aún asi, no deberemos pensar que las "básicas disposiciones corporales" son un sustento últımo de las construcciones metafóricas. Para Wheelwright, las dimensiones del cuerpo sólo son visibles una vez que reparamos en las colncidencias de los símbolos arquetípicos, esto es, una vez que las metáforas petriflcadas en estos simbolos nos han permitido concebir el "cuerpo" y sus disposiciones fundamentales. La misma percepción es ya lingüistıca, y por tanto lingüistica es nuestra propla percepción del cuerpo. Lakoff \& Johnson señalan Igualmente este detalle en el libro citado: "En otras palabras, lo que llamamos "experiencla física directa" nunca es simplemente una cuestión del hecho de que tenemos un cuerpo de un clerto tipo: más bien toda experiencla tiene lugar dentro de un amplio conjunto de presuposiciones culturales. Puede ser, por tanto, engañoso hablar de experiencla fisłca directa como si hubiera algun núcleo 
de experienclas inmedlatas que nosotros interpretáramos en términos de nuestro sistema conceptual (...) Seria más correcto decir que toda experiencla es cultural hasta los tuétanos, que experimentamos nuestro mundo de tal manera que nuestra cultura ya está presente en la experiencla misma" (op. cit., p. 97).

La conclusión que extrae de este estudio Wheelwright va a permitirle abrir un resquiclo en la trama del lenguaje. A la vista de la importancia de ciertos simbolos en la constitución del pensamiento y de la concepción del mundo de los pueblos (padre-cielo, madre-tierra, luz, sangre, arriba-abajo, el eje de la rueda, etc...). Wheelwright afirma que cualquier grado significativo del pensamiento es impostble sin lenguaje, del mismo modo que el lenguaje lo es a su vez sin actluldad metafórica patente o velada. Y la concreclón de clertas metáforas en simbolos tensivos constituye una fase natural del proceso.

¿Y que nos aparece al observar este momento de la génesis del lenguaje, el momento en que la palabra nace como "metáfora"? Aparece la realidad primera, el mundo-como-experiencla del hombre primitivo, un mundo que es sensación de las presencias ocultas y latentes de las cosas que nos rodean. El mundo "presenclal". De tal manera que este mundo que surge en el acto metafórico, al Igual que éste, tiene dos momentos:

- la situación epifórica se produce doquiera ve el hombre a través de lo inmediato una clerta realidad en acecho;

- por otro lado, el mito diafórico se posibilita en cuanto el hombre obra la sintesis de dos o más formas cargadas de "presencia": la Mujer, la Vaca, y la Luna creclente.

La conclusion del estudio de Wheelwright es la siguiente: tras presenciar como el lenguaje humano se articula fundamentalmente desde los actos de captación metafórica aflora una concepción de la realidad cuyas principales caracteristicas parecen ser tres:

a) la realidad es presenclal y tensiva:

b) es unitaria y se caracteriza por la compenetración entre sus elementos:

c) es "perspectiva", y por ello latente, y se nos revela sólo de manera parclal y ambigua, y a través de una oblicuidad sı́mbólica.

La metáfora poética, de este modo. se convierte en un caso especial de la entraña metafórica del lenguaje y su razón (la razón de que constituya el elemento primordial del poema, el instrumento poético por excelencia) estriba en la necesidad del poeta de encontrar la palabra precisa, el gesto desvelador. En ocasiones -dice Wheelwright- el poeta Intenta comunicar la simplicidad de la experiencia recordada mediante una total sencillez de expresión. Sin embargo, la simplicidad, cuando es algo vivo y no banal, dificilmente puede ser comunicada salvo en los raros casos en que, por feliz 
accidente, dos sensibllidades se encuentran casualmente sintonizadas en ese aspecto. Para lograr una comunicación más firme el poeta debe elaborar una "simulación" ( $\mu t \mu \eta \sigma i \varsigma$ ) de la simplicidad. Puesto que el poeta no puede esperar ser ayudado por una sintonización perfecta, su trabajo consistirá en parte en hacer leves sugerenclas capaces de suscitar la respuesta adecuada en los espiritus que estén alerta. La metáfora en poesia es, por tanto, el gesto desesperado por hacerse entender.

\section{Una primera apraxtmación de Ortega}

Bajo el epigrafe "Tabú y metáfora" Ortega profundiza en las razones que hacen necesaria la metáfora. Tras aflrmar como la metáfora es un rastro divino, un poder taumatürgıco, "la potencla más fértil que el hombre posee", señala: "Es verdaderamente extraña la existencia en el hombre de esta actividad mental que consiste en suplantar una cosa por otra, no tanto por afán de llegar a ésta como por el empeño de rehulr aquélla. La metáfora escamotea un objeto enmascarándolo con otro, y no tendria sentıdo si no viéramos bajo ella un instinto que induce al hombre a evitar realidades" (op. cit., pg. 74).

El origen de la metáfora está, pues, en el espíritu del tabú. La metáfora es una forma lingüistica de evitar referirse a lo prohibido, a lo que da mledo...

"Obtenido de este forma tabuista, el instrumento metafórico puede luego emplearse con los fines más diversos. Uno de éstos, el que ha predominado en la poesia, era ennoblecer el objeto real. Se usaba de la imagen similar con Intención decorativa, para ornar y recamar la realidad amada" (op. cit., 75).

En este fragmento Ortega conclbe la metáfora enfrentada al lenguaje de la "realidad". Se precisa aquélla justamente para rehuir éste. Y tal espírttu genético de evitación que concierne a cualquiera de los actos humanos, deviene en la poesia mero recurso estético, objeto de ornato.

Más adelante estudiaremos unas págınas de Ortega que desdicen las opiniones presentadas y que además nos ayudarán sobremanera a elaborar una crítlca certera. Pasemos a la reflexión ahora que tenemos ante nosotros la posibllidad de entablar diálogo.

Apunte critico. Consecuencias ontologicas de la deflnición de Artstóteles

Hemos podido apreciar cómo los autores estudiados colnciden en partir de la definición de Arıstóteles a la hora de ofrecer una defintción precisa de 
metáfora. Blen es clerto que sus apreclaciones ahondan en la naturaleza de la metáfora más que lo hiclera el Estagirita, pero, aún asi, en ningún momento se plantean sı en el punto de partida el fenómeno metafórico fue justamente descrito, o si cabe poner algun reparo. $Y$, sin embargo, se puede defender que la metáfora, tal como la deflne Aristóteles, es un acto lingüistico fallido que comporta una ontologia insostenlble. Y que, por consigulente, si el fenómeno metafórico no puede ser definido de otra forma, si no nos es posible entender por "metáfora" algo diferente, entonces los desvelos que habiamos puesto en su estudio se toman estérlles.

Según Aristóteles "la metáfora consiste en dar a una cosa un nombre que pertenece a otra cosa". Y, como afirma Wheelwright, tal transferencia de nombres implica la suposición de que algo es cuando no lo es. Contamos, pues, en la metáfora con dos planos de referencia: lo que se dice "ser" tal cosa, y lo que se dice "ser tal cosa sin serlo". Esto es, lo que se nombra como "realidad" y lo que se nombra como "falsificación", como "ficción", como "fantasma". Con lo cual, en el fondo, hemos vuelto a toparnos con un viejo dual ismo: el del "ser" y la "aparlencia"; aquello que es y aquello que parece ser pero no es.

Fermando Pessoa caracteriza espléndidamente este juego de ocultaclones en que parece consistir la metáfora. Dice asi:

"Damos comúnmente a nuestras ideas de lo desconocido el color de nuestras nociones de lo conocido: si llamamos a la muerte un sueño, es porque parece un sueño por fuera: si llamamos a la muerte una nueva vida, es porque parece una cosa diferente de la vida. Con pequeños malentendidos con la realidad construimos las creenclas y las esperanzas, y vivimos de las certezas a las que llamamos panes, como los niños pobres que Juegan a ser felices. Pero asi es toda la vida: asi, por lo menos, es ese sistema de vida particular al que, en general, se llama civilización. La clvilización consiste en dar a algo un nombre que no le compete, y después sonar sobre el resultado. $Y$, realmente, el nombre falso y el sueño verdadero crean una nueva realidad. El objeto se vuelve realmente otro. Manufacturamos ideales. La materia prima sigue siendo la misma, pero la forma, que el arte le ha dado, la aleja de continuar siendo efectivamente la misma. Una mesa de pino es pino pero tamblén es mesa. Nos sentamos a la mesa y no al pino. Un amor es un instinto sexual, pero no amamos con el instinto sexual, sino con la presuposición de otro sentimiento. $Y$ esa presuposición es ya. en efecto, otro sentimiento" (op. cit., pp. 53-54).

Parece ser la metáfora una suerte de falsiflcación tortuosa, pues incluso aquél que la opera queda seducido por el proceso de transmutación y llega a creerse la "realidad" soñada y pretendida una nueva realidad. Pero el problema es más grave. Es mayúsculo. Pues asi es toda la vida asegura Pessoa. La metáfora, como leíamos lineas atrás, no se puede reduclr a 
simple recurso estllistico, fenómeno que domlnásemos a voluntad y proplciásemos únicamente en la ocaslón del acto poético, de tal modo que pudiésemos hacer convivir sin contradicciones un lenguaje cotidiano de la "realidad" y un lenguaje metafórico de la "flcción". Por el contrario, la metáfora está en la entraña del lenguaje, es el instrumento de innovación por excelencla. Ocurre la metáfora en todo momento en que se trata de expresar una individualidad, esto es, aquello que exige ser dicho en lo que tlene de pecullar, de "suyo", en su ser propio.

Admitiendo la "circunstancia" como profuslón camblante de acontecimientos, no nos es dificil concebir el lenguaje en su radicalidad (esto es, el lenguaje cuando es tensión, pálpito, decisión de decir, y no mecánico uso de un código) como ese esfuerzo por nombrar la nueva aparición (ésta, aqui, ahora) que la cosa, flujo constante de manifestaciones de ser, ofrece en el momento preciso en que es enfocada, en que es proplciada. Ontologia fundamental del enunciado-acontecimlento.

Y ya que don Fernando Pessoa asi nos lo ha ofrecido, quizás deberiamos hacer un comentarlo sobre lo "conocido" y lo "desconocido". Porque no es lo "desconocido" únicamente un ámbito que integrasen aquellas cosas que nunca se han presentado a nuestro conocimiento (èste seria el concepto de "desconocido" del realista mostrenco), sino incluso todas aquellas manifestaclones aún no presenctadas de las cosas que ya creemos conocer. Desde la lejanía que supone el acto de percepclón el sujeto capta una perspectiva del objeto, una faceta. En ocasiones la faceta es Insólita: "yo así no te conozco", decimos al "conocido" que se ha comportado de forma Inesperada. El intelecto, y su portavoz el lenguaje, tienen que hacer un esfuerzo por remitir al objeto la nueva visión; es la tensa búsqueda de una palabra que logre reconstruir el objeto a partir de aquella cara que en ese instante logra mostrar. El sortllegio más poderoso para conseguir "decir" la cosa, "aprehender" la cosa, es la metáfora.

Pues blen: si admitimos que la metáfora es el mejor instrumento de innovación lingüistica, y si tambièn admitımos que toda palabra ha sido en algún momento fruto de tal procedimiento. pues toda palabra fue en algún momento una innovación, entonces la "transmutación" en que consiste la metáfora empapa todo el lenguaje humano. Siguiendo los términos de Wheelwright, podriamos afirmar que el lenguaje humano, desde su ser fundamentalmente metafórico, nos muestra un palsaje "metamórflco" en el que nada es lo que parece ser y todo es otra cosa. Todo aparecer es máscara: ni słquiera lo que llamamos "realıdad" escapa al embrujo, porque la certeza que lo real nos procura no es más que platónica pérdida de memorla: una consecuencla de haber olvidado la transformación que lo produjo. Las charcas están llenas de prínclpes hechizados (¿o tal vez sean los palacios los que están llenos de ranas desmemorladas?). Tendriamos 
que aflrmar, como lo hace Pessoa, que nuestras expectativas son sueños tejidos con malentendidos, "y que vivimos de las certezas que llamamos panes, como los niños pobres que juegan a ser fellces". En esta situación deberiamos también admitir que todo es farsa y que no hay punto de reposo, atalaya segura... A es $B, y$ B es $C$, y $C$ es $D$, y $D$ es... y asi slempre. Aceptar esta posibilidad sería aceptar la imposlbilidad del lenguaje.

Claro que tal vez podamos superar la diffultad y salir del entuerto. Para ello se nos ofrecen dos vias de solución.

Por una parte, algunos sostienen la existencla de una referencla últuma que acabaria con la infinitud de la "cadena metafórica". Esto es, se postula la existencla de un lenguaje referencial primigenlo que sirve de base a toda construcción metafórica posterior. Es esta propuesta una evidente peticlón de principio, mito de la Creación: Yahvé otorga el poder del lenguaje al hombre para que éste de nombre a las cosas. El lenguaje primigenlo es el lenguaje de Adán, el lenguaje mágico que hace presente la cosa en el mismo acto de nombrarla. Un lenguaje que no conlleva ninguna fractura entre palabra y cosa nombrada: se dice lo que es.

Podemos tomar en constderaclón algunos argumentos que anularian esta hipótesis de un lenguaje genétjco y referencial. En primer lugar, no hay por que aceptar que el mito de la creaclón del lenguaje se pueda contar desde la única perspectiva del designio divino. En segundo lugar, aún en el caso de que se admita la intervención de los dioses en la creación del lenguaje según la versión mítica más sostenible (aquélla que relata el acuerdo primitivo entre los dioses y los hombres, y que afirma su continua renovación cada vez que se vuelve a pronunclar un "nombre"), tal acto de diálogo poseeria unas condiclones que en absoluto podrian asegurarnos el establecimiento de un lenguaje no metafórico, de un concepto puro. $Y$ esto es fácllmente comprensible si nos percatamos de que una génesis dialéctica de la palabra (poetızada en el dlálogo entre dioses y hombres) excluye la

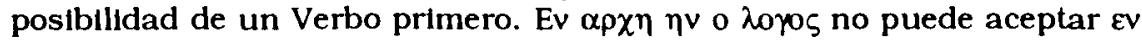
$\alpha \rho \chi \eta \eta \vee$ o $\delta 1 \alpha \lambda o \gamma o \zeta$. Más adelante intentaremos exponer que la propla esencia de lo metafórico es el fundamento dialéctico del lenguaje, y que, por tanto, no cabe admitir un mito que señale la posibilidad de un lenguaje sin hablantes (una dificultad que ya apreciaron los teólogos y que intentaron soslayar ideando un divino solitario parlanchin, un Dios que se conoce a sí mismo, que se habla a si mismo, esto es, un Dios que, a pesar de poseer el Verbo en su Integridad, está internamente escindido en hablante y oyente).

Otros fllósofos en busca de un lenguaje genético postularon una versión laíca del "primum parlante", y acudieron a las kinestesias, a las disposiciones corporales básicas. Es el caso de los fenomenólogos husserlianos y, en lo que concierne a nuestro objeto de estudio, de muchos 
flósofos del lenguaje. Este planteamiento a primera vista es seductor. Sin embargo no tlene en cuenta un detalle que no se le escapó a Wheelwright. Cuando exponiamos las lineas generales de su estudio vimos que, observando el proceso de gestación de los simbolos arquetipicos, Wheelwright destacaba como muchas metáforas se convertian en símbolos persistentes para el ser humano graclas a que tales metáforas insistian en "semejanzas naturales de la constitución fisica y psiquica del hombre". Por supuesto, las referidas semejanzas únicamente son visibles graclas al acto metafórtco que ha redundado en ellas y que, tras hacerlas "habituales", produce una especle de "lenguaje universal del cuerpo". De tal modo que, aquella capacidad que para los husserllanos o para los innatistas chomskyanos es antertor a la metáfora, y, por tanto, condiclón de su posibilidad, para Wheelwright es ya una consecuencia, un efecto metafórico. No hay cuerpo prelingüistico que postbllite desde el mismo, desde sus puras coordenadas, cualquier transmutación Imaginativa. porque el propio cuerpo es ya una existencla metafórtca. Es resultado de una costumbre metafórica, desde su kinesteslas más simples hasta la percepción más compleja. El cuerpo, como blen señalaban Lakoff y Johnson, es un efecto del lenguaje.

Ya que no nos satisfacen ninguna de las dos posibilidades tendremos que buscar una tercera solución. Supongamos que todos los problemas que afrontamos se originan en la definición de Aristóteles. Supongamos que Aristóteles defintó inadecuadamente la metáfora y nos es necesario, si seguimos pensando que el acto metafórico es crucial en la construcción de un lenguaje, revisar la deflniclón clásıca e intentar proponer otra que salve las difncultades planteadas. Volvamos a las págınas de Ortega.

La metáfora como dialéctica. Reflexión a partír dé un texto dé Ortega

En un texto que sirve de prólogo al libro El Pasajero, de J. Moreno Villa, y que lleva por título "Ensayo de Estética a manera de Prólogo", Ortega estudia una metáfora del poeta levantino López Picó. Dice el verso que el ciprés

$$
\text { e com l'espectre d'una flama morta }
$$

Y se pregunta Ortega: ¿cuál es en esta metáfora el objeto metafórico? "No es el ciprés ni la llama ni el espectro: todo esto pertenece al orbe de las imágenes reales. El objeto nuevo que nos sale al encuentro es un "clprésespectro de una llama". Ahora bien tal clprés no es un clprés, ni tal espectro un espectro, ni tal llama una llama. Si queremos retener lo que puede del ciprés quedar una vez hecho llama y de ésta hecha ciprés, se reduce a la nota real de identidad que existe entre el esquema lineal del cıprés y el esquema líneal de la llama. Esta es la semejanza real entre una 
cosa y otra. En toda metáfora hay una semejanza real entre sus elementos, y por esto se ha creido que la metáfora consistia esenclalmente en una asimllación, tal vez en una aproximación asimilatorla de cosas muy distantes.

Esto es un error. En primer lugar, esa mayor o menor distancia entre las cosas no puede querer decir sino un mayor o menor parecido entre ellas; muy distantes, por lo tanto, equivale a muy poco parecidas. Y sin embargo, la metáfora nos satisface precisamente porque en ella averiguamos una coincidencia entre dos cosas más honda y dectsiva que cualesqulera semejanzas" (op. clt., pg. 153).

En estas lineas ya se vislumbra el giro de Ortega con respecto a la concepclón clásica de la metáfora. Lo metafórico no és una asimilación entre cosas distantes. No consiste la metáfora en la "uniflcación" de los objetos puestos en relación a partir de la semejanza que podamos establecer entre ellos. Y puesto que la "unificación" no existe, tampoco se podrá dar la "suplantaclón" de una cosa por la otra. De tal modo que, en la metáfora, no parece haber base alguna para que nos esté permitido tomar una cosa en lugar de la otra.

¿Qué es pues la metáfora?

El mecanismo -sugiere Ortega- acaso sea el siguiente: se trata de formar un nuevo objeto que llamaremos el "clprés bello", en oposición al ciprés real. Para alcanzarlo es preciso someter éste a dos operaciones.

En primer lugar, aniquilar el ciprés real. El aniquilamiento del objeto que Ortega llama "real" va a producirse justamente a partir de la desemejanza que mantiene con el objeto metafórico. Al asimilar lo desemejante (valiéndonos de pequeñas semejanzas irrelevantes), los objetos plerden sus límites: se convierten ambos, ciprés y llama, en otras cosas. Ambos se transforman. Buscamos una identidad Inesencial para afirmar la Identidad absoluta, dice Ortega. Pero -prosigue- esto es absurdo, es imposible. Porque la pequeña semejanza real sirve en rigor para acentuar la desemejanza real entre ambas cosas. Donde la identuficaclón real se veriflca no hay metáfora. Hay deflnición. En la metáfora viue la conclencia clara de la notdentidad. Llama, ciprés, espectro, abandonan sus estrictos limites reales para fluidificarse en un puro molde ideal, en una como tendencia imaginativa.

El resultado de esta primera operaclón -concluye Ortega- es, pues, el aniquilamiento de las cosas en lo que son como imágenes reales. Al chocar una con otra rómpense sus rígidos caparazones y la materla Interna, en estado fundente, adquiere una blandura de plasma, apto para recibir una nueva forma y estructura. El resultado de la primera operación ha consistido, pues, en que la cosa clprés y la cosa llama comienzan a fluir y se tornan en tendencia tdeal ciprés y tendencia Ideal llama. Y este resultado 
sorprendente y los acontecimientos referidos nos procuran una perspectiva del acto metafórico que differe radicalmente de aquélla que nos ofrecia la definición etímológica, de manera tal que sólo a partir del giro obrado podemos introducirnos en la entraña de la metáfora. Pues, dice Ortega, la palabra "metáfora" Indica etimológicamente la posición de una cosa en lugar de otra. Sin embargo, la transferencia es en la metáfora stempre mutua; lo cual sugiere que el lugar donde se pone cada una de las cosas no es el de la otra. sino un lugar sentimental, que es el mismo para ambas. En conclusión, la metáfora consiste en la transposición de una cosa desde su lugar real a su lugar sentimental.

Con lo cual, el fenómeno se muestra desde una faceta que slempre ha permanecido oculta para cualquier teoria referenclalista del significado, en definitiva, para cualquier realismo epistemológico, ya sea aristotélico o de corte Ferdinand Saussure. Pues estas teorias mantlenen como punto de partıda y principlo básico la necesidad de que la palabra encuentre su fundamento en ella misma, ya sea en la cosa que es su referencla, o en la imagen mental que es su significado. La palabra es un "absoluto", un ente que se explica desde sî mismo y en sí mismo cobra sentido. De manera tal que, Incluso cuando la palabra tiene que salir de si, esto es, cuando es transportada en el acto metafórico, no pueden dejar de seguir mantenlendo tales teorias la persistencia de una referencla última: la metáfora, aseguran, consiste en la identincación de un término "imaginario" con un término "real". Las "aparienclas" se salvan considerándolas trasuntos de "realidad".

Al cabo, en semejante juego de manos, la metáfora queda falseada y convertida en aquella procesión de fantasmagorias en busca de reposo último de que hablábamos lineas atrás.

La mirada que nos ofrece Ortega es mucho más penetrante: nos devuelve al momento genétlco en el que se gestan las posibilldades de significación. Pues en la metáfora, en ese pecullar instante de creactón lingüistica, los términos que se han encontrado en un mitlco lugar sentimental se convierten en un plasma fecundo para retornar con las limitaciones que se han otorgado mutuamente. Ambos vuelven otros. Y en las estrellas estarán mirando los ojos de la amada, y en los ojos de la amada brillarán estrellas; tras el sortllegio, las estrellas obtendrán la facultad de ver y los ojos quedarán convertidos en objetos astrales.

La metáfora no ha consistido de ningún modo en "ponerse una cosa en lugar de otra". Ha consistido, por el contrario, en "posibllitarse una cosa graclas a la otra" mediante la gestación de dos nuevas palabras que resurgen con diferentes perflles tras su encuentro. Justamente los que se han dado una a la otra cuando han sido ojo-estrella, o, sigulendo la metáfora de Ortega, ciprés-llama-espectro. 
Aflora en esta concepción un espectáculo del lenguaje que sobrepasa con creces la pobre perspectiva a la que nos tenian acostumbrados los "gramáticos". Pues las teorias referencialistas desprecian a los hablantes (apoyándose en la división clásica de Saussure de "lengua" y "habla", esto es, de "semántica" y "pragmática") e Incluso clerran las puertas a la posibilidad del "decir", pues éste solamente puede ser con rigor posibilidad de un "nuevo decir". Nunca "léxico". Nunca "lengua". La palabra no llega a estar dicha de una vez por todas; es slempre esfuerzo por decir. Un acto doloroso, agónico... Desprecian los gramáticos a los hablantes porque aceptan la poslbilidad de un lenguaje al que no le afectaria el acto de habla, un lenguaje clausurado y construldo estructuralmente a pesar de sus acontecimientos, tan pétreo, tan inerte, que incluso es factuble emprender la descripción pormenorizada de sus significados (ese conjunto de "rasgos" que proponia Chomsky). Como si el lenguaje no dependiese de una decisión por decir.

La situación se extrema tanto que el lenguaje, escarnecido, se convierte en un mero intercambio de códigos inertes, y lo habla una máquina. Es la era de la información, de la comunicación, de la informática, de la náusea. Los técnicos del lenguaje introducen el principio de inercia: la ley de lo muerto.

Sin embargo, el lenguaje humano no tiene sentido sin el discurso humano; las palabras surgen propicladas por la intención de hablar. Son un querer decir que nunca deja de ser empeño, pues un único impulso no llega a agotar las continuas posibilidades del acontecer, las continuas manifestaclones de la cosa. Tiene que caber la posibilidad de un nuevo acercamiento que conflera un nuevo sentido; de un nuevo enunclado que desvele un nuevo acontecimiento.

Las palabras en su punto de encuentro, en el acto metafórico, entran como en un crisol, se refunden y cobran por la magla alquímica nuevas propledades.

Y de este modo podriamos decir que el discurso humano es dialéctico en un doble sentido: dialéctico porque el minimo acto lingüistico (incluso la conversación del alma consigo mismal es diálogo, es acto de habla, es propiclación de la palabra en la relación humana, en el intercambio; es dialéctico también el lenguaje porque sus palabras surgen y cobran significado en el encuentro, mostrando, como dijera Borges, las "ocultas simpatias" que entre ellas mantienen.

Pero volvamos a las páginas de Ortega. La segunda operación que en su opintón completa el acto metafórico es la siguiente: una vez advertidos de que la identidad no está en las imágenes reales, insiste la metáfora tercamente en proponérnosla. Y nos empuja a otro mundo donde por lo visto es aquélla posıble: ese nuevo mundo donde los cipreses son llamas. 
$\mathrm{Y}$, ¿no es este nuevo mundo el único posıble justamente por ser "posibilidad de manifestaclón"? Nuevo mundo de la metáfora, a la postre taumaturgla y misterio. "El sentimiento clprés y el sentimiento llama son idénticos. ¿Por qué? ‘Ah! no sabemos por qué; es lo Irracional del arte, es el absoluto empirismo de la poesía. Cada metáfora es el descubrimiento de una ley del untverso. Y, aún después de creada una metáfora, seguimos ignorando su por qué. Sentimos, simplemente, una identidad, vivimos ejecutlvamente el ser ciprés-llama" (Ortega, op. cit., pg. 157-158).

Y si descubrimos otro mundo, con otras leyes, ¿evitamos acaso aquél en el que estábamos situados? ¿Por qué?, ¿por mledo tal vez, como nos decia Ortega páginas atrás, cuando justificaba la metáfora a partır del tabú?

¡No! En la metáfora no se rehuye la "realidad". Se rehuye la realidad baldia, la anqullosada, la realidad muerta, que al cabo no es más que una "metáfora muerta", esto es, una metáfora que, hipostasiada, reducida a una categoria del ser, ha perdido la relaclón dialéctica que mantenia con el resto de los objetos metafóricos que la conflguraban y se ha convertido en un simple y mostrenco objeto "referencial", un objeto que pasa a Incrementar el bagaje de las "realidades conflrmadas".

La realidad palpltante, que ha nacido en el sortilegio de la metáfora, muere en el concepto. Y la expresión de éste, su definiclón, no es más que el espectro de lo que la palabra en su momento cruclal pudo decir.

Por tanto, el hombre no evita realidades temiendo su "poder", como el Judio evitaria nombrar a Dlos temiendo la acusación de impledad. Por el contrarto, es la impotencia lo que su instinto reconoce. Es la Imposibilidad de ofrecer nuevas apariciones lo que descubre en aquella realidad estértl que se ha determinado a la unilinealidad del signo y ha perdido la multivocidad que poseia cuando era simbolo. Cuando la cosa ha perdido la capacidad de ser parousia continua y se ha determinado a ser únicamente su "nombre" (identidad con su nombre, lo que se dice ser, lo que es, ti Eon -fallecimiento de la luz que ocurre indefectiblemente cuando la palabra mágica, desveladora, se convierte en palabra clentiflca, en definición-) la cosa deviene no-ser, y el hombre la rehuye. O mejor dicho, el hombre rehuye su cadáver para, en la lèjania, revivirla. Esto es justamente lo que Heidegger llamaba "cuidar del ser": ocuparse en descubrir y evitar los seres que han caido en el "olvido" -olvido que es desconocimiento de la génesis dialéctica, metafórica de las cosas, en el

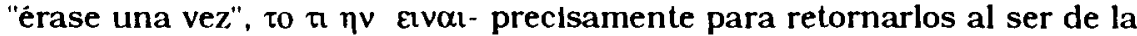
presencia mediante un nuevo acto poético. Retornar del olvido lo que fueron las ranas cuando las abuelas sabian contar cuentos. 


\section{BIBLIOGRAFIA}

BORGES, Jorge Luis, "Historia de la Eternidad", en Prosa, Barcelona, Círculo de Lect ores, 1985. ORTEGA Y GASSET, José, La deshumanización del arte y otros ensayos de Estética Madrid. Espasa Calpe. 1987.

PESSOA Fernando, Libro del desasosiego. Barcelonna. Selx Barral. 1988.

TURBAYNE. Coln Murray, El mito de la metáfora. México, F.C.E.. 1974.

WIIELWRIGHT, Philip, Metáfora y realidad, Madrid, Espasa Calpe, 1979 